\title{
Performance of Wheat (Triticum aestivum L.) under Need based Nitrogen Management Strategies and Different Tillage Options
}

\author{
Mizanul Haque, Mainak Ghosh* and Tejpratap \\ Department of Agronomy, Bihar Agricultural University, Sabour 813210, Bhagalpur, India \\ *Corresponding author
}

\section{A B S T R A C T}

\begin{tabular}{|c|}
\hline $\begin{array}{l}\text { K e y w o r d s } \\
\text { Zero tillage, } \\
\text { conservation } \\
\text { agriculture, } \\
\text { transplanted rice and } \\
\text { cropping system }\end{array}$ \\
\hline Article Info \\
\hline $\begin{array}{l}\text { Accepted: } \\
\text { 04 February } 2018 \\
\text { Available Online: } \\
10 \text { March } 2018\end{array}$ \\
\hline
\end{tabular}

Sensor based smart technologies can lead a way in increasing wheat production for small and marginal farmers with the save guard of sustainable environment using adequate synthetic fertilizer. Field plot experiment was conducted having conventional tillage (CT) and zero tillage (ZT) in main plots and five nutrient management viz., $\mathrm{N}_{1}$ and $\mathrm{N}_{2}$ with top dressing after and before irrigation, respectively having similar recommended dose, $\mathrm{N}_{3}$ based on Nutrient Expert tool, $\mathrm{N}_{4}$ using nutrient expert tool in combination with Green Seeker and $\mathrm{N}_{5}$ (nutrient enriched plot) in sub plots. The experiment was laid out in split plot design with three replications during the dry season of 2014-15 and 2015-16. Results indicated that across the two tillage options, the nutrient expert tool with green seeker based $\mathrm{N}$ application could save the $\mathrm{N}$ fertilizer by $30 \%$ without affecting the grain yield of wheat crop. This smart technology $\left(\mathrm{N}_{4}\right)$ also increased the net return by Rs. 4643 and Rs. 10574 over the $100 \%$ and $150 \%$ recommended dose of $\mathrm{N}$, respectively. Research findings strongly suggest the need of revision in current nutrient recommendations for wheat crop and aiming that nutrient expert tool and green seeker can be the viable option for higher productivity and profitability of wheat crop.

\section{Introduction}

Wheat (Triticum aestivum L.) is one of the most important cereals in the human diet in different countries of the world since time immemorial. The national productivity of wheat is not quite enough and the rising population poses the unrivaled pressure on agricultural production system. Despite of smart technologies the wheat grain production per unit application of nutrient has been decreased continuously (Lpez-Bellido et al., 2005; Ghosh et al., 2017) resulting poor Nutrient use efficiency (40-50\% for $\mathrm{N}$ and 20 -
$40 \%$ for P) and partial factor productivity. Hence, there is an urgent need to increase the nutrient use efficiency from the view point of sustainability. Site specific need based nitrogen management strategies are very dynamic to bridge the gap between supply and demand. The large variation in soil $\mathrm{N}$ status and blanket fertilizer application following improper general recommendation by the farmers lead to over application of $\mathrm{N}$ fertilizer. The main reason for poor $\mathrm{N}$ use efficiency is inefficient splitting of $\mathrm{N}$ dose coupled with excess $\mathrm{N}$ application leads to low $\mathrm{N}$ use efficiency in wheat (Singh et al., 2010). 
Increment of $\mathrm{N}$ use efficiency can be obtained only when the application will coincide with most hungry stages with adequate amount that reduce the losses (Diacono et al., 2013). From sustainable point of view, the $\mathrm{N}$ management in wheat needs to be refined for improving $\mathrm{N}$ use efficiency, crop productivity and profitability, and minimizing fertilizer $\mathrm{N}$ loss to the environment. The blanket $\mathrm{N}$ dose varying from 100 to $180 \mathrm{~kg} \mathrm{~N}^{-1}$ indicates huge spatial variation and farmers are often apply in more than two splits. In fact farmers often apply an extra dose of $\mathrm{N}$ to avoid the risk of deficiency as it is linked with irrigation events. In many regions farmers are applying $\mathrm{N}$ fertilizer at levels that exceed the dose suggested by the government extension services (Takebe et al., 2006; Singh et al., 2011). The hand held Greenseeker (Trimble Navigation Limited, Sunnyvale, CA, USA) is an active optical crop canopy sensor with a red $(650 \pm 10 \mathrm{~nm})$ and a NIR $(770 \pm 15 \mathrm{~nm})$ is commercially available and used widely. By measuring the strength of the reflected light, the sensor shows a numeric reading of NDVI (Normalized Difference Vegetation Index) between 0.00 and 0.99. Raun et al., (2001) noted expected yield as determined from NDVI has strong relationship with the actual grain yield in winter wheat. Using NDVI measurements of wheat at different times during crop growth period, Raun et al., (2001, 2002) developed concepts of response index and potential yield, to define a fertilizer nitrogen algorithm for the $\mathrm{N}$ requirement in winter wheat based on expected yields as well as achievable greenness of the leaves. Raun et al., (2002) showed that prediction of wheat response to $\mathrm{N}$ applications guided by optical sensor was positively correlated to measured $\mathrm{N}$ response and increased $\mathrm{N}$-use efficiency. Under need based management strategy Nutrient Expert (NE) developed International Plant Nutrition Institute, USA) is also good option, computer based decision support software for wheat and smallholder farmers.
$\mathrm{NE}$ is a nutrient decision support software that uses the principles of site-specific nutrient management (Dobermann and Witt, 2004; Witt et al., 2009) and enables farm advisors to develop fertilizer recommendations tailored to a specific field or growing environment. NE uses a systematic approach of capturing information from farmers' field, which is important for developing a location-specific recommendation. As a computer-based decision support tool, NE combines all the steps and guidelines in site specific nutrient management into simple software tailored for farm advisors. Nutrient Expert allows the users to draw required information from their own experience, farmers' knowledge of the local region and farmers' practices. With NE, parameters can be estimated using proxy information, which allows farm advisors to develop fertilizer guidelines for a location without data from field trials. Excessive tillage operation in conventional farming also has the negative environmental impacts such as soil erosion, groundwater pollution and atmosphere contamination. Jat et al., (2009) reported that direct seeding or zero tillage is alternative option, as the researchers suggested its wide applicability in many crops around the world and this technology has potential to allow saving in time, energy, water and labour during crop establishment. The major objective of the present investigation was to test whether Nutrient Expert tool or Greenseeker based $\mathrm{N}$ fertilizer management in wheat was appropriate under zero/conventional tillage for managing fertilizer $\mathrm{N}$ in irrigated wheat.

\section{Materials and Methods}

\section{Experimental site}

Field experiment was conducted during rabi season of 2014-15 and 2015-16 in the research farm of Bihar Agricultural University, Sabour, Bhagalpur $\left(25^{\circ} 15^{\prime} 40^{\prime \prime} \mathrm{N}\right.$ latitude, $87^{\circ} 2^{\prime} 42^{\prime \prime} \mathrm{E}$ 
longitude and an elevation of $37.0 \mathrm{~m}$ a.s.l.), India for precision $\mathrm{N}$ management in wheat using green seeker and nutrient expert tool under zero and conventional tillage. The soil of the experimental plot was sandy loam in texture, low in nitrogen (179 kg/ha) and organic carbon (0.55) and medium in available $\mathrm{P}_{2} \mathrm{O}_{5}(23 \mathrm{~kg} / \mathrm{ha})$ and $\mathrm{K}_{2} \mathrm{O}(183 \mathrm{~kg} / \mathrm{ha})$, neutral in reaction (soil pH 7.05) and non-saline in nature. The climate of Sabour is characterized by hot and humid during summer (April and May), rainy during June to September, moderately hot and dry during autumn (October and November), cool and dry during winter (December and January) and moderate in spring (February and March). The site receives annual average rainfall of $1200 \mathrm{~mm}$ of which $70-75 \%$ occurred in the monsoon months (June to October). The average temperature varies from $19^{\circ} \mathrm{C}$ in December/January to $29.6^{\circ} \mathrm{C}$ in May/June.

\section{Experimental details and treatments}

The experiment was laid out in split plot design with three replications consisting of two tillage options i.e., conventional tillage (CT) and zero tillage (ZT) in main plots and five nutrient (N) management viz., recommended dose (150:60:40 $\mathrm{kg}$ $\mathrm{N}: \mathrm{P}_{2} \mathrm{O}_{5}: \mathrm{K}_{2} \mathrm{O}$ ha $^{-1}$ ) with top dressing after irrigation $\left(\mathrm{N}_{1}\right)$, recommended dose with top dressing before irrigation $\left(\mathrm{N}_{2}\right)$, nutrient management based on Nutrient Expert tool $\left(\mathrm{N}_{3} ; 125: 63: 105 \mathrm{~kg} \mathrm{~N}: \mathrm{P}_{2} \mathrm{O}_{5}: \mathrm{K}_{2} \mathrm{O}\right.$ ha $\left.^{-1}\right)$, nutrient management based on nutrient expert tool $(70 \% \mathrm{~N})+$ remaining $\mathrm{N}$ as guided by Green Seeker $\left(\mathrm{N}_{4} ; 105: 63: 105 \mathrm{~kg} \mathrm{~N}: \mathrm{P}_{2} \mathrm{O}_{5}: \mathrm{K}_{2} \mathrm{O} \mathrm{ha}^{-1}\right)$ and nutrient enriched plot having $150 \% \mathrm{~N}$ and $\mathrm{P}_{2} \mathrm{O}_{5} \& \mathrm{~K}_{2} \mathrm{O}\left(225: 60: 40 \mathrm{~kg} \mathrm{~N}: \mathrm{P}_{2} \mathrm{O}_{5}: \mathrm{K}_{2} \mathrm{Oha}^{-1}\right)$ as per recommendation $\left(\mathrm{N}_{5}\right)$ in sub plots. All the treatments received 50\% $\mathrm{N}$ and full dose of $\mathrm{P}_{2} \mathrm{O}_{5}$ and $\mathrm{K}_{2} \mathrm{O}$ during final land preparation except $\mathrm{N}_{3}$ and $\mathrm{N}_{4}$. The $\mathrm{N}$ was top dressed in the form of urea at $25 \%$ each at CRI and jointing stages of wheat crop. The sources of chemical fertilizers were urea, single super phosphate and muriate of potash.

\section{Crop management}

Wheat variety 'HD 2733' was used for this investigation. It was the most popular variety of wheat grown in India for several decades and provides good yield. It takes about 130135 days to mature in Bihar, India. Basal dose of fertilizer as per the treatments was applied and incorporated in each plot at one day before sowing of wheat. Wheat crop was sown on 25th November in the year 2014 and 2015 at spacing of $20 \mathrm{~cm}$ between rows.

\section{Observations recorded}

An area $5 \mathrm{~m}^{2}$ from each plot was ear-marked for destructive sampling and the rest of the plot was used for biological yield estimation. Various biometric data were recorded at different growth stages of the crop from the ear-marked area of each plot and economic yield was estimated at final harvest. The number of earhead $\mathrm{m}^{-2}$, number of grains earhead $^{-1}$ and test weight of grain were recorded from each plot at maturity. The crop was harvested from $5 \mathrm{~m}^{2}$ area for yield estimation in each plot. After threshing the grain and straw were dried in the sun for 3-4 days and corrected to $12 \%$ moisture content. The economics of wheat cultivation was calculated on the basis of government approved rate and prevailing market price of various inputs and outputs in the local markets. The cost of different cultural operations was computed on the basis of fixed cost and variable cost. The cost of cultural operations common for all the treatments such as sowing seeds, weeding and irrigation are put under fixed cost and those vary with treatments like the field preparation, fertilizers and their application, harvesting and processing costs are put under variable cost. The cost per unit yield for harvest and 
processing was calculated using measured mean yield under various treatments tested in consultation with the published standard costs for harvesting and processing of the crop. The net return was calculated by deducting the production cost from the gross value of the produce, including by-product value (gross return) and the benefit: cost ratio was measured on net return basis.

\section{Statistical analysis}

The data were analyzed statistically by applying "Analysis of Variance" (ANOVA) technique of RCBD (Cochran and Cox 1985). The significance of different sources of variations was tested by Error mean square of Fisher Snedecor's 'F' test at probability level 0.05 . Least significant difference (LSD) at $5 \%$ level of significance was worked out for each character of the experiment.

\section{Results and Discussion}

The yield attributes and economic yield of wheat crop did not vary significantly between the two tillage options, however significant variation has been observed among the nutrient management practices. The mean grain yield of wheat in conventional tillage yielded non significantly higher mean grain yield (44.76 $\mathrm{qha}^{-1}$ ) than that of the zero-tillage (44.0 $\mathrm{qha}^{-1}$ ) and it was due to the yield attributes did not vary significantly among the main plots (Table 1). This showed that wheat sown either in zero tillage or conventional tillage provided similar wheat yield (Jat et al., 2009). Among the different $\mathrm{N}$ management practices, Nutrient Expert tool $(70 \% \mathrm{~N})+$ remaining $\mathrm{N}$ as guided by Green Seeker recorded higher mean grain of $49.44 \mathrm{q} \mathrm{ha}^{-1}$ and was statistically at par with the mean grain yield of recorded from Nutrient Expert tool $\left(45.24 \mathrm{q}^{-1}\right)$ and intern were significantly superior to the mean grain yield obtained in other nutrient management practices. In our study, nutrient expert tool $\left(\mathrm{N}_{3}\right)$ and nutrient expert Tool with green seeker guided $\left(\mathrm{N}_{4}\right)$ nutrient management practices received lower dose of $\mathrm{N}$ rate as compared to that of $\mathrm{N}_{1}, \mathrm{~N}_{2}$ and $\mathrm{N}_{5}$ i.e. 100 to $150 \% \mathrm{~N}$ dose and were found most encouraging $\mathrm{N}$ management in increasing yield and yield attributes of wheat crop. The result indicated that $105 \mathrm{~kg} \mathrm{~N}$ for wheat through nutrient expert and green seeker guided tool lead to good nutrient supply throughout the growing periods of wheat and may able to save about $45 \mathrm{~kg} \mathrm{~N}^{-1}$ $(30 \%)$ when compared with normal recommendation practices $\left(\mathrm{N}_{1}\right.$ and $\left.\mathrm{N}_{2}\right)$ without affecting the grain yield of the crop. The treatment $\mathrm{N}_{5}$ received highest dose of $\mathrm{N}$ (225 $\mathrm{kg} \mathrm{ha}^{-1}$ ) and able to facilitate high vegetative growth rather than reproductive output. Sui et al., (2013) and Ghosh et al., (2017) noticed that biomass production under high $\mathrm{N}$ fertilized fields was faster and higher than that of optimized $\mathrm{N}$ treatments at vegetative stages but not at the reproductive stages.

The maximum earhead and grains were also observed in Green Seeker guided N treatment, whereas the test weight did not differ significantly among the treatments. The high $\mathrm{N}$ fertilizer $\left(\mathrm{N}_{5}\right)$ did not affect the yield attributes and may lead to poor $\mathrm{N}$ use efficiency and environment degradation. The nutrient expert tool evaluated the potassium dose and it was $>2.5$ times than the existing dose of $\mathrm{K}$. The further study and survey is very needful in this area for a concrete conclusion in recommended dose of $\mathrm{K}$ for wheat cultivation. From the economic point of view, the net return and $\mathrm{B}: \mathrm{C}$ ratio were found significantly higher in nutrient expert with green seeker guided treatment $\left(\mathrm{N}_{4}\right)$ than that of other nutrient management practices. The treatment $\mathrm{N}_{4}$ recorded $50.5 \%$ higher net return and $19 \%$ more benefit: cost ratio when compared with the $\mathrm{N}_{5}$ having the highest fertilizer dose (Table 1). 
Table.1 Yield attributing characters, yield, and economics as influenced by varying tillage options and different $\mathrm{N}$ management practices in wheat

\begin{tabular}{|c|c|c|c|c|c|c|}
\hline Treatments & $\begin{array}{l}\text { No of ear } \\
\text { head } / \mathrm{m}^{2}\end{array}$ & $\begin{array}{c}\text { Grains/Ear } \\
\text { head }\end{array}$ & $\begin{array}{c}\text { Test } \\
\text { weight (g) }\end{array}$ & $\begin{array}{l}\text { Yield } \\
\text { (q/ha) }\end{array}$ & $\begin{array}{l}\text { Net Return } \\
\text { (Rs.) }\end{array}$ & $\begin{array}{c}\text { B:C } \\
\text { Ratio }\end{array}$ \\
\hline \multicolumn{7}{|c|}{ Main Plot } \\
\hline Zero tillage & 263 & 40.66 & 41.17 & 44.00 & 68404 & 1.99 \\
\hline Conventional Tillage & 267 & 40.57 & 41.25 & 44.76 & 65436 & 1.87 \\
\hline CD (0.05) & NS & NS & NS & NS & NS & NS \\
\hline \multicolumn{7}{|c|}{ Sub Plot } \\
\hline $\mathrm{N} 1 *\left(150: 60: 40 \mathrm{~kg} \mathrm{ha}^{-1}\right)$ & 266 & 40.52 & 41.37 & 44.57 & 27357 & 2.02 \\
\hline N2 $\left(150: 60: 40 \mathrm{~kg} \mathrm{ha}^{-1}\right)$ & 262 & 41.01 & 41.33 & 43.79 & 26405 & 2.00 \\
\hline N3 $\left(125: 63: 105 \mathrm{~kg} \mathrm{ha}^{-1}\right)$ & 268 & 40.91 & 41.42 & 45.24 & 27605 & 2.01 \\
\hline N4 (105: 63:105 kg ha' $\left.{ }^{-1}\right)$ & 273 & 41.80 & 42.64 & 49.44 & 31524 & 2.13 \\
\hline N5 (225:60:40 $\left.\mathrm{kg} \mathrm{ha}^{-1}\right)$ & 259 & 39.31 & 39.32 & 39.73 & 20950 & 1.79 \\
\hline $\mathrm{CD}(0.05)$ & 8 & 1.08 & NS & 5.12 & 1978 & 0.09 \\
\hline
\end{tabular}

*The numbers indicate the nutrient dose of $\mathrm{N}: \mathrm{P}_{2} \mathrm{O}_{5}: \mathrm{K}_{2} \mathrm{O} ; \mathrm{CD}=$ Critical difference

The increase in economics in $\mathrm{N}_{4}$ was associated with increase in grain yield with less use of $\mathrm{N}$ fertilizer over that of higher recommended dose in $\mathrm{N}_{1}, \mathrm{~N}_{2}$ and $\mathrm{N}_{5}$ (Diacono et al., 2013; Peng et al., 2012; Ghosh et al., 2017). The result indicated that the Nutrient Expert in combination with green seeker may be the best option for higher productivity of wheat crop at lowest cost leading to more profitability and sustainability.

The nutrient expert tool with green seeker based $\mathrm{N}$ application can be used for sustainable wheat production. Herein, significant increment in grain yield was observed with the saving of considerable amount of $\mathrm{N}$ in using nutrient expert tool in combination with green seeker guided $\mathrm{N}$ management strategy.

This smart technology increased net return by Rs. 4643 over $100 \%$ recommended dose of nutrient and by Rs. 10574 over $150 \%$ recommended dose of $\mathrm{N}$. Our findings indicated that revision of current recommendations of nutrient for wheat cultivation and aiming to using nutrient expert tool and green seeker for higher productivity and profitability of wheat crop.

\section{References}

Cochran, W. G. and Cox, G. M. 1985. Experimental Designs, 2nd edn, 576. Bombay, India: Asia publishing House.

Diacono, M., Rubino, P. and Montemurro, F. 2013. Precision nitrogen management of wheat: A review. Agronomy for Sustainable Development, 33:219-241.

Dobermann, A. and C. Witt. 2004. In Dobermann, A., C. Witt and D. Dawe. (eds.), Increasing productivity of intensive rice systems through sitespecific nutrient management. Enfield, NH (USA) and Los Baños (Philippines): Science Publishers, Inc., and International Rice Research Institute (IRRI), pp. 75-100.

Ghosh, M., Swain, D. K., Jha, M. K. and Tewari, V. K. 2017. Chlorophyll meterbased nitrogen management of wheat in eastern India. Experimental Agriculture. http://dx.doi.org/10.1017/S0014479717 000035.

Jat, M. L., Gathala, M. K., Ladha, J. K., Saharawat, Y. S., Jat, A. S., Kumar, Vipin, Sharma, S. K., Kumar, V. and Gupta, R. 2009. Evaluation of precision land leveling and double zero-till systems in the rice-wheat rotation: 
Water use, productivity, profitability and soil physical properties. Soil \& Tillage Research, 105: 112-121.

Lopez-Bellido, L., Lopez-Bellido, R. J. and Redondo, R. 2005. Nitrogen efficiency in wheat under rainfed Mediterranean conditions as affected by split nitrogen application. Field Crops Research, 94: 86-97.

Peng, L. L., Ying, L. Y., Guo, L. S. and Long, P. X. 2012. Effects of nitrogen management on the yield of winter wheat in cold area of northeastern China. Journal of Integrative Agriculture, 11(6): 1020-1025.

Raun, W. R., Johnson, G. V., Stone, M. L., Solie, J. B., Lukina, E. V., Thomason, W. E. and Schepers. J. S. 2001. In season prediction of potential grain yield in winter wheat using canopy reflectance. Agronomy Journal, 93(1): 131-138.

Raun, W. R., Solie, J. B., Johnson, G. V., Stone, M. L., Mullen, R. W., Freeman, K. W., Thomason, W. E. and Lukina, E. V. (2002). Improving nitrogen use efficiency in cereal grain production with optical sensing and variable rate application. Agronomy Journal, 94: 815-820.

Singh, B., Sharma, R. K., Kaur, J., Jat, M. L., Martin, K. L., Singh, Y., Singh, V., Chandna, P., Choudhary, O. P., Gupta, R. K., Thind, H. S., Singh, J., Uppal, H.
S., Khurana, H. S., Kumar, A., Uppal, R. K., Vashistha, M., Raun, W. R. and Gupta, R. 2011. Assessment of the nitrogen management strategy using an optical sensor for irrigated wheat. Agronomy for Sustainable Development 31(3): 589-603.

Singh, V., Singh, B., Singh, Y., Thind, H. S. and Gupta, R. K. 2010. Need based nitrogen management using the chlorophyll meter and leaf colour chart in rice and wheat in South Asia: A review. Nutrient Cycling in Agroecosystem, 88: 361-380.

Sui, B., Feng, F., Tian, G., Hu, X., Shen, Q. and Guo, S. (2013). Optimizing nitrogen supply increases rice yield and nitrogen use efficiency by regulating yield formation factors. Field Crops Research, 150: 99-107.

Takebe, M., Okazaki, K., Karasawa, T., Watanabe, J., Ohshita, Y. and Tsuji, H. 2006. Leaf colour diagnosis and nitrogen management for winter wheat, "Kitanokaori" in Hokkaido. Soil Science Plant Nutrition, 52: 577.

Witt, C., J.M. Pasuquin, M.F. Pampolino, R.J. Buresh and A. Dobermann. 2009. A manual for the development and participatory evaluation of site-specific nutrient management for maize in tropical, favorable environments. Available at http://seap.ipni.net, pp. 30.

\section{How to cite this article:}

Mizanul Haque, Mainak Ghosh and Tejpratap. 2018. Performance of Wheat (Triticum aestivum L.) under Need based Nitrogen Management Strategies and Different Tillage Options. Int.J.Curr.Microbiol.App.Sci. 7(03): 118-123. doi: https://doi.org/10.20546/ijcmas.2018.703.013 